\title{
PEMBEKALAN KEWIRAUSAHAAN KEPADA PELAJAR SMA MUHAMMADIYAH MELALUI METODE BUSINESS MODEL CANVAS (BMC)
}

\author{
Beny $^{1}$, Klemens Wedanaji P. ${ }^{2}$ \\ ${ }^{1}$ Trisakti School of Management \\ ${ }^{2}$ Trisakti School of Management
}

beny@stietrisakti.ac.id, klemens@stietrisakti.ac.id

\begin{abstract}
Abstrak
Kewirausahaan merupakan hal universal yang dapat dilakukan dari berbagai kalangan usia termasuk pelajar SMA. Pelajar SMA patut mendapat pembekalan kiat-kiat untuk berwirausaha yang baik sejak dini. Berwirausaha tentu tidak hanya berbicara tentang hal teoritis melainkan juga aplikasi daripada ilmu kewirausahaan yang sudah dipelajari. Beberapa sekolah saat ini pun sudah memiliki kurikulum kewirausahaan di dalam proses belajar mengajarnya, namun proses tersebut belum dapat secara optimal mendorong para pelajar untuk menciptakan suatu ide bisnis yang dituangkan ke dalam sebuah proposal bisnis. Trisakti School of Management sebagai suatu lembaga pendidikan tinggi yang berfokus pada bidang akuntansi dan manajemen memberikan pembekalan kepada para pelajar dari SMA Muhammadiyah mengenai bagaimana cara mengaplikasi ilmu kewirausahaan yang telah dipelajari sebelumnya. Tujuan dari kegiatan ini adalah untuk membekali setiap siswa siswi yang memiliki semangat berwirausaha agar dapat mengerti dan memahami serta mengaplikasikan ide bisnisnya dengan menggunakan metode yang tepat. Pembekalan dilakukan dengan memperkenalkan suatu metode perencanaan bisnis yakni Business Model Canvas (BMC). Business Model Canvas sebagai sebuah strategi dalam manajemen yang berupa visual chart yang terdiri dari 9 elemen dapat memberikan gambaran perencanaan bisnis yang lebih komprehensif namun relatif lebih mudah untuk dimengerti dan diaplikasikan. Melalui pengenalan akan Business Model Canvas ini, para pelajar SMA Muhammadiyah dapat menuangkan dan mengaplikasikan ide bisnis mereka ke dalam 9 elemen tersebut dengan lebih terstruktur dan terperinci, sehingga mempermudah proses penyusunan proposal bisnis.
\end{abstract}

Kata Kunci : Kurikulum, Business Model Canvas, dan Business Plan

\section{PENDAHULUAN}

Pertumbuhan ekonomi negara-negara Asia Tenggara (ASEAN) khususnya Indonesia, Malaysia, Filipina, Singapura, Thailand dan Vietnam, mencapai 5 persen pada tahun 2011, dan ditargetkan menjadi 5,6 persen selama tahun 2012-2016, 2 persen lebih rendah dibanding tahun 2010.
Permintaan dari luar tidak tumbuh terlalu banyak, maka ekonomi ASEAN beralih ke penggerak pertumbuhan domestik dalam jangka menengah dan mulai menggali sebagai strategi alternatif untuk perkembangan jangka panjang. Ketidakpastian global dan tantangan baru, sifat pertumbuhan di Asia berubah menjadi lebih seimbang. Jenis baru pertumbuhan ekonomi dibutuhkan di Asia Tenggara, 
ketidakpastian global adalah peluang untuk menciptakan ulang pertumbuhan (Pezzini, 2012 dalam Sukirman, 2017). Untuk mencapai pertumbuhan ekonomi di Indonesia dalam ketidakpastian global, perlu melakukan pemberdayaan usaha kecil yang dianggap mampu mengembangkan produksi. Sesuai dengan program pemerintah ditargetkan 5 juta wirausaha baru sampai dengan 2025 dengan mengembangkan sumber daya manusia untuk kemajuan wirausaha nasional (Sukirman, 2017).

Menurut Van Praag dan Versloot (2007) dalam Adnyana dan Purnami (2016), kewirausahaan sering dikaitkan untuk merangsang pertumbuhan ekonomi, inovasi, pekerjaan dan kreasi usaha. Penelitian empiris juga mendukung hubungan positif antara aktivitas kewirausahaan terhadap pertumbuhan ekonomi. Kewirausahaan dapat dikatakan merupakan salah satu faktor penentu bagi kemajuan suatu Negara. Pertumbuhan ekonomi dapat dicapai jika negara memiliki banyak wirausaha (Siswadi, 2013). Menurut David Mc Clelland (2009) dalam Siswadi (2010), suatu negara bisa makmur kalau jum $\neg$ lah entrepreneur (wirausaha) sedikitnya ada $2 \%$ dari total populasi penduduk. Pada tahun 2007, jumlah wirausaha di Amerika Serikat mencapai $11,5 \%$, sementara di singapura setidaknya ada $7.2 \%$. Indonesia menurut data dari BPS (2010) diperkirakan hanya sebesar $0,18 \%$ (sekitar 400.000 dari yang seharusnya 4,4 juta). Dengan kata lain bahwa wirausaha adalah pelaku penting dari kegiatan ekonomi modern saat ini.

Kewirausahaan pertama kali muncul pada abad 18 diawali dengan penemuan-penemuan baru seperti mesin uap, mesin pemintal, dll. Tujuan utama mereka adalah pertumbuhan dan perluasan organisasi melalui inovasi dan kreativitas. Keuntungan dan kekayaan bukan tujuan utama. Secara sederhana arti wirausahawan (entrepreneur) adalah orang yang berjiwa berani mengambil resiko untuk membuka usaha dalam berbagai kesempatan berjiwa berani mengambil resiko artinya bermental mandiri dan berani memulai usaha, tanpa diliputi rasa takut atau cemas sekalipun dalam kondisi tidak pasti (Kasmir, 2007 dalam Suhermini, 2010). Berjiwa berani mengambil resiko identik dengan sikap yang dimiliki oleh palajar. Berwirausaha tidak hanya terbatas pada mereka yang sudah dewasa dan memiliki banyak pengalaman dn pertimbangan yang matang. Para pelajar pun dapat berwirausaha, termasuk juga para pelajar tingkat SMA.

Peraturan Pemerintah Republik Indonesia Nomor 19 Tahun 2005 tentang Standar Nasional Pendidikan pasal 26 menyiratkan bahwa pendidikan pada SMA tidak hanya terbatas pada pencapaian hasil belajar saja namun juga keterampilan agar siswa memiliki kemampuan untuk dapat hidup secara mandiri setelah menyelesaikan pendidikan pada jenjang SMA. Namun pada kenyatannya Data Badan Pusat Statistik (BPS) menunjukkan bahwa jumlah pengangguran terbanyak adalah dari lulusan tingkat SMA dan sederajad. Tingginya angka pengangguran di Indonesia disebabkan lulusan SMA yang tidak melanjutkan pendidikan ke perguruan tinggi, jumlah lapangan pekerjaan yang terbatas dan tidak adanya keterampilan yang dimiliki siswa lulusan SMA untuk dapat hidup mandiri, misalnya keterampilan berwirausaha (Kristandi et al, 2012). Para pelajar diberi pendidikan keterampilan berwirausaha agar kelak mereka tidak hanya menjadi pencari kerja tetapi juga dapat menjadi penyedia lapangan kerja. Oleh karena itu, penting bagi para pelajar untuk mendapat pendidikan kewirausahaan sejak dini.

Menurut Fatoki (2014) dalam Adnyana dan Purnami (2016), sekolah bisnis menjadi jembatan antara pengetahuan teoritis dan keterlibatan praktis di lapangan. Terkait dengan pengaruh pendidikan kewirausahaan tersebut, perlu adanya pemahaman tentang bagaimana dan mendorong lahirnya wirausaha-wirausaha muda yang potensial sementara mereka berada dibangku pendidikan. Beberapa sekolah saat ini pun sudah memiliki kurikulum kewirausahaan di dalam proses belajar mengajarnya. Kurikulum ini dimaksudkan untuk memberikan dasar-dasar kewirausahaan bagi para pelajar. Namun, menurut Aprilianty (2012), proses pembelajaran di SMK belum sepenuhnya mampu membangun potensi kepribadian wirausaha. Berwirausaha tentunya bukan hanya berbicara mengenai dasar-dasar teoritis yang dipelajari. Berwirausaha bukan hanya berbicara mengenai dasar teoritis, namun juga berbicara mengenai praktek yang mendorong para pelajar untuk secara optimal menciptakan ide bisnis yang dituangkan ke dalam sebuah proposal bisnis.

Menurut Zimmerer (2002) dalam Suharti dan Sirine (2011), salah satu faktor pendorong

$$
\text { Ekonomi, Sosial, dan Budaya }
$$


pertumbuhan kewirausahaan disuatu negara terletak pada peranan universitas melalui penyelenggaraan pendidikan kewirausahaan. Trisakti School of Management sebagai suatu lembaga pendidikan tinggi yang berfokus pada bidang akuntansi dan manajemen juga ikut berperan aktif dalam penyelenggaraan pendidikan kewirausahaan. Trisakti School of Management beperan dalam penyelenggaran pedidikan kewirausahaan bukan hanya untuk mahasiswa, namun juga untuk pelajar SMA. Dalam hal ini, Trisakti School of Management memberikan pembekalan kepada para pelajar dari SMA Muhammadiyah mengenai bagaimana cara mengaplikasikan ilmu kewirausahaan yang telah dipelajari sebelumnya. Tujuannya adalah agar para pelajar SMA Muhammadiyah dapat memvisualkan ide bisnis dengan terstruktur dan terperinci.

Pembekalan oleh Trisakti School of Management dilakukan dengan memperkenalkan suatu metode perencanaan bisnis yakni Business Model Canvas (BMC). Business Model Canvas mempresentasikan perencanaan bisnis melalui tiga unsur utama yaitu product, value, dan Market. Keunggulan dari Business Model Canvas adalah dapat memberikan gambaran perencanaan bisnis yang lebih komprehensif namun relatif lebih mudah untuk dimengerti dan diaplikasikan.

Para pelajar dari SMA Muhammadiyah diberi pemaparan mengenai sembilan pilar inti dalam Business Modal Canvas yang akan membantu mereka dalam memvisualkan ide bisnis mereka. Kemudian para pelajar dibagi dalam beberapa kelompok. Tiap-tiap kelompok diberi arahan untuk memvisualkan ide bisnisnya sesuai dengan pilarpilar dalam Business Model Canvas yang telah dipaparkan. Ide bisnis yang telah divisualkan dalam Business Model Canvas menjadi suatu blueprint yang terstruktur dan terperinci bagi para pelajar untuk menjalankan bisnis tersebut. Dengan Business Model Canvas, para pelajar dapat mendapat gambaran yang lebih jelas untuk menjalankan bisnis mereka.

\section{METODE}

Kegiatan dilakukan selama 3 kali pertemuan di mana pertemuan pertama siswa siswi dibekali dengan dasar - dasar mengenai kewirusahaan, mengapa seseorang perlu berwirausaha, dan bagaimana dapat menciptakan sebuah ide bisnis menarik yang dapat dikembangkan ke depannya. Untuk dapat menumbuhkembangkan minat siswa agar berkarir sebagai wirausaha maka dibutuhkan upaya untuk meningkatkan faktor kepribadian mereka. Faktor kepribadian meliputi kebutuhan akan berprestasi, locus of control, bersahabat dengan ketidakpastian, dan keberanian mengambil risiko serta percaya diri. Faktor kepribadian tersebut dapat dipupuk dan ditingkatkan melalui pengembangan softskill mereka. Di samping itu, perbaikan kurikulum, metode pembelajaran, dan pengajaran tetap perlu untuk dibenahi (Kurnianto dan Putra, 2012 dalam Siswadi, 2013). Pertemuan kedua, siswa siswi dibekali dengan pencatatan akuntansi secara sederhana, mempersiapkan laporan keuangan dasar yang dibutuhkan dalam membangun bisnis, dan analisis kelayakan proyek. Pertemuan ketiga, siswa siswi dibekali dengan konsep atau teori mengenai suatu metode perencanaan bisnis yaitu Business Model Canvas (BMC).

Menciptakan anak didik yang siap kerja dengan kemampuan dan keterampilan yang memadai, menjadi sebuah tuntutan agar anak didik mampu mandiri dan tidak tergantung pada pemerintah. Kemandirian untuk berwirausaha inilah yang sangat diperlukan agar industry - industri semakin tumbuh berkembang dan pengangguran semakin terkikis (Kuntowicaksono, 2012). Di dalam sebuah bisnis, apapun bentuknya, pastinya ada beberapa orang yang mengoperasikan agar kegiatan usaha terus berjalan. Di dalam sebuah bisnis juga memerlukan strategi, manajemen, maupun sistem yang mempermudah orang-orang di dalamnya untuk bekerja secara efektif dan sesuai goals yang dimiliki perusahaan. Pembekalan yang diberikan kepada siswa siswi dengan menggunakan suatu metode perencanaan bisnis yang dinamakan dengan Business Model Canvas (BMC), yaitu alat representasi visual 
yang dapat menjelaskan secara komprehensif sebuah proses bisnis. Menurut Osterwalder dan Pigneur (2018), bisnis model kanvas adalah sebuah strategi dalam manajemen yang berupa visual chart yang terdiri dari 9 elemen. Secara garis besar, alurnya mengalir dari satu elemen bisnis menuju elemen penting berikutnya. Berikut adalah sembilan elemen yang terdapat dalam bisnis model kanvas: (Osterwalder dan Pigneur, 2018) 1) Customer segment adalah elemen pertama yang harus dimiliki dalam memulai bisnis model kanvas ini adalah menentukan segmen pelanggan mana yang akan menjadi target bisnis. Menurut Kotler dan Keller (2016), segmentasi merupakan pembagian sebuah pasar menjadi beberapa kelompok pembeli yang berbeda. Segmentasi pasar dapat dimaksudkan sebagai pembagian pasar yang berbeda - beda (heterogen) menjadi kelompok - kelompok pasar yang homogen, di mana setiap kelompoknya bisa ditargetkan untuk memasarkan suatu produk sesuai dengan kebutuhan, keinginan, ataupun karakteristik pembeli yang ada di pasar tersebut. Misalnya, suatu maskapai penerbangan mengeluarkan dua produk untuk memenuhi kebutuhan dua segmen pelanggan yang berbeda, atau ada dua stasiun televisi yang menyajikan dua acara berbeda untuk memenuhi segmen pelanggan yang berbeda, 2) Value Proposition adalah sekat yang merupakan keunggulan produk, apa saja sesungguhnya poin poin yang dapat mendatangkan manfaat yang ditawarkan perusahaan bagi customer segment-nya. Hal ini menjadi kesempatan untuk menjabarkan kekuatan dan keunggulan yang membedakan bisnis yang satu dengan bisnis yang lain, 3) Channel adalah media yang digunakan untuk men-deliver solusi yang ditawarkan untuk sampai kepada konsumen. Channel ini bisa berupa website, online advertisement, aplikasi, bahkan seorang sales person, 4) Customer relationship yaitu merupakan elemen di mana perusahaan menjalin ikatan dengan pelanggannya, perlu pengawasan yang ketat dan intensif agar pelanggan tidak mudah berpaling ke bisnis yang lain hanya karena jalinan hubungan yang kurang baik, 5) Revenue stream merupakan bagian yang paling vital, di mana organisasi memperoleh pendapatan dari pelanggan. Elemen ini harus dikelola semaksimal mungkin untuk meningkatkan pendapatan bisnis. Jangan sampai ada bahan baku, produk, atau kinerja yang tidak dimanfaatkan secara maksimal, 6) Key activities adalah semua aktivitas yang berhubungan dengan produktivitas bisnis yang berkaitan dengan sebuah produk, di mana kegiatan utamanya adalah menghasilkan proposisi nilai, 7) Key resource adalah sekat dalam bisnis model kanvas yang berisikan daftar sumber daya yang sebaiknya direncanakan dan dimiliki perusahaan untuk mewujudkan value proposition mereka. Semua jenis sumber daya, mulai dari pengelolaan bahan baku, penataan sumber daya manusia, dan penataan proses operasional menjadi perhatian dalam membuat model bisnis, 8) Key partnership yaitu berfungsi untuk pengorganisasian aliran suatu barang atau layanan lainnya. Posisi-posisi partner kunci tersebut bermanfaat untuk efisiensi dan efektivitas dari key activites yang telah dibuat. Tak ada salahnya menjalin hubungan baik untuk menciptakan siklus bisnis sesuai dengan ekspektasi, dan 9) Cost structure, elemen terakhir yang tak kalah pentingnya dengan kedelapan elemen lainnya adalah struktur pembiayaan bisnis. Mengelola biaya secara efisien akan membuat bisnis yang dijalani menjadi lebih hemat dan bisa meminimalkan risiko kerugian. Hal ini juga dapat menentukan proposisi nilai yang tepat untuk pelanggan.

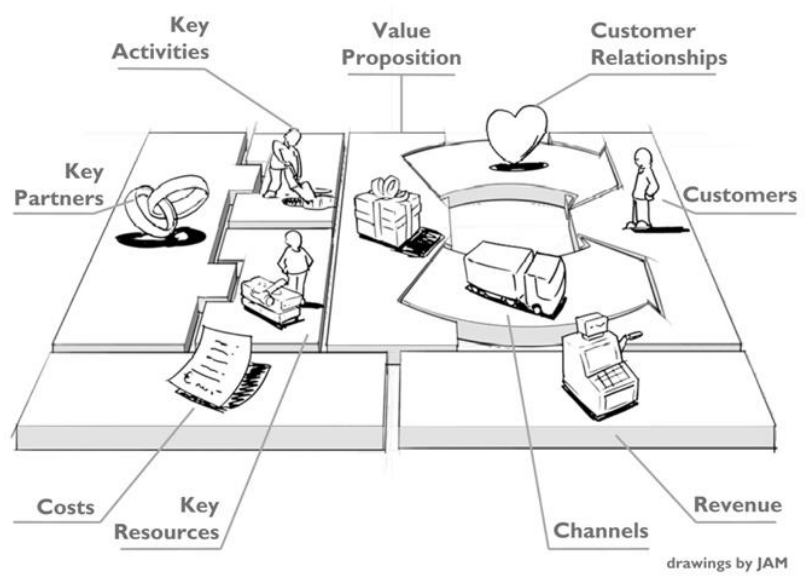

Gambar 1. Business Model Canvas

Ekonomi, Sosial, dan Budaya

1243 


\section{HASIL DAN PEMBAHASAN}

Kegiatan yang dilakukan pada pertemuan pertama yaitu pembekalan dengan memberikan pemahaman mengenai dasar - dasar kewirausahaan kepada siswa siswi. Mereka diberikan pemahaman tentang mengapa perlu adanya melakukan kegiatan wirausaha, menjelaskan tentang karakter seorang wirausaha, tipe - tipe wirausaha, serta menumbuhkan keinginan untuk menjadi seoranh wirusaha. Pada pertemuan ini, siswa siswi memahami perbedaan antara menjadi seorang karyawan dan menjadi seorang wirausaha, sehingga mereka mulai dapat berpikir alasan untuk menjadi seorang wirausaha. Siswa siswi dibekali dengan pemahaman mengenai karakter yang harus dimiliki dalam menjadi seorang wirausaha, kesuksesan dan kegagalan dalam menjadi seorang wirausaha, serta tips dalama menangkap peluang bisnis. Proses untuk mengembangkan sebuah usaha baru terjadi pada proses kewirausahaan (entrepreneur process), yang melibatkan lebih dari sekedar penyelesaian masalah dalam suatu posisi manajemen. Seorang pengusaha harus menemukan, mengevaluasi, dan mengembangkan sebuah peluang dengan mengatasi kekuatan yang menghalangi terciptanya suatu yang baru. Proses ini memilki empat tahap yang berbeda: 1)Identifikasi dan evaluasi peluang, 2)Pengembangan rencana bisnis, 3)Penetapan sumber daya yang dibutuhkan, 4)Manajemen perusahaan yang dihasilkan. Identitas peluang dan evaluasi merupakan tugas yang sangat sulit. Sebagian besar peluang bisnis yang baik tidak muncul secara tiba - tiba melainkan merupakan hasil ketajaman seseorang pengusaha melihat kemungkinan pada beberapa kasus, pembentukan mekanisme yang dapat mengidentifikasi peluang potensial (Rosmiati, et al., 2015).

Pada pertemuan kedua, siswa siswi mendapatkan pembekalan tentang bagaimana membuat pencatatan sederhana mengenai setiap transaksi yang terjadi, memahami proses dalam menyusun laporan keuangan, serta analisis kelayakan proyek. Dalam pertemuan ini siswa siswi memahami menghitung dan menetapkan harga jual dari produk dan harga pokok penjualannya, mereka dapat mengelompokkan biaya - biaya apa saja yang timbul dari bisnis yang dijalankannya sampai kepada laba operasi dan laba bersih yang diperoleh. Setelah itu siswa siswi dapat membuat analisis kelayakan proyek secara sederhana dengan menghitung arus kas operasi yang diperoleh dari berjalannya bisnis tersebut.

Pada pertemuan ketiga, siswa siswi diajarkan mengenai sebuah konsep baru dalam menciptakan dan menjalankan sebuah ide bisnis yaitu dengan menggunakan Business Model Canvas (BMC). Model bisnis adalah gambaran hubungan antara keunggulan dan sumber daya yang dimiliki perusahaan, serta kegiatan - kegiatan yang dilakukan untuk mengakuisisi dan menciptakan nilai, yang membuat perusahaan mampu menghasilkan laba. Dengan konsep ini, siswa siswi memahami tentang bisnis yang dibangun mulai dari siapa yang dilayani, apa yang ditawarkan, bagaimana cara menghasilkan produk, bagaimana cara menghasilkan uang atau laba, dan bagaimana membedakan dirinya secara strategis terhadap pesaing, Dalam hal menyusun bisnis model ini, siswa siswi memahami ada empat manfaat apabila memiliki model bisnis, yaitu: 1) memudahkan para perencana dan pengambil keputusan di perusahaan melihat hubungan logis antara komponen - komponen dalam bisnisnya, 2) membantu menguji konsistensi hubungan antar komponennya, 3) membantu menguji pasar dan asumsi yang digunakan ketika mengembangkan bisnis, dan 4) menunjukkan sebarapa radikal suatu perubahan dilakukan dan konsekuensinya. Pada pertemuan ini, siswa siswi memahami dalam menyusun 9 pilar kerangka model bisnis kanvas yaitu customer segment, value proposition, channel, customer relationship, revenue stream, key activities, key resources, cost structure, dan key partnership. 


\section{KESIMPULAN}

Dari kegiatan yang telah dilakukan selama tiga hari pada siswa siswi di SMA Muhammadiyah, membuat siswa siswi dapat memahami dan mengaplikasikan setiap konsep dan metode yang diberikan untuk mengembangkan minat serta bakat menjadi seorang wirausaha. Mulai dari memahami alasan menjadi seorang wirausaha serta karakter yang harus dimiliki, proses pencatatan transaksi dan menyusun laporan keuangan serta analisis kelayakan, penerapan Business Model Canvas (BMC) sebagai sebuah metode untuk menciptakan ide bisnis yang sesuai dengan kebutuhan masyarakat saat ini. Melihat kepada kebutuhan masyarakat yang beragam, pengaplikasian dengan menggunakan Business Model Canvas (BMC) dapat menjadi sebuah metode yang tepat untuk siswa siswi dalam menjalankan ide bisnis mereka dengan menuangkan kepada sembilan elemen tersebut, sehingga bisnis yang dibangun menjadi terstruktur dan dapat diukur dengan jelas serta masyarakat dapat merasakan betul setiap manfaat dari bisnis yang dijalankan oleh mereka.

\section{REFERENSI}

Adnyana, I Gusti Lanang Agung., Purnami, Ni Made. (2016). Pengaruh Pendidikan Kewirausahaan, Self Efficacy, dan Locus of Control Pada Niat Berwirausaha. E-Jurnal Manajemen Unud, 5(2): 1160-1188.

Aprilianty, Eka. (2012). Pengaruh Kepribadian Wirausaha, Pengetahuan Kewirausahaan, dan Lingkungan Terhadap Minat
Berwirausaha Siswa Smk. Jurnal Pendidikan Vokasi, 2(3): 311-324.

Kotler, Philip., Keller, Kevin Lane. (2016). Marketing Management. Pearson Education.

Kristanti, Ely Ana., Bintari, Siti Harnina., Ridlo, Saiful. (2012). Pengembangan Perangkat Pembelajaran Bioentrepreneurship Pembuatan Makanan Dari Limbah Cair Pengolahan Kedelai Journal of Innovative Science Education, 1(2).

Kuntowicaksono. (2012). Pengaruh Pengetahuan Wirausaha dan Kemampuan Memecahkan Masalah Wirausaha Terhadap Minat Berwirausaha Siswa Sekolah Menengah Kejuruan. Journal of Economic Education, 1(1).

Osterwalder, Alexander., Pigneur, Yves. (2018). Business Model Generation. PT Elex Media Komputindo.

Rosmiati, Junias, Donny Teguh Santosa., Munawar. (2015). Sikap, Motivasi, dan Minat Berwirausaha Mahasiswa. Jurnal Manajemen dan Kewirausahaan, 17(1): 21-30.

Siswadi, Yudi. (2013). Analisis Faktor Internal, Faktor Eksternal dan Pembelajaran Kewirausahaan yang Mempengaruhi Minat Mahasiswa dalam Berwirausaha. Jurnal Manajemen dan Bisnis, 13(1).

Suharti, Lieli., Sirine, Hani. (2011). Faktor -

Faktor yang Berpengaruh Terhadap Niat Kewirausahaan (Entrepreneurial Intention). Jurnal Manajemen dan Kewirausahaan, 13(2): 124-134.

Sukirman. (2017). Jiwa Kewirausahaan dan

Nilai Kewirausahaan Meningkatkan Kemandirian Usaha Melalui Perilaku Kewirausahaan. Jurnal Ekonomi dan Bisnis, 20(1). 